\title{
Stability Analysis of Southern Slope of Chenmenshan Open Pit Copper Mine
}

\author{
Mohammed Mnzool, Ling Wan and Zuoan Wei \\ College of Resource and Environmental Science, Mining Engineer, Chongqing University, Chongqing 400030, China \\ Received 2013-07-13, Revised 2013-07-28; Accepted 2013-07-29
}

\begin{abstract}
Chengmenshan Copper SulphurMine, one of the of the large-scale open pit mine in China, the engineering geology and hydrogeology in the Southern slope of the mine is very complicated and the contact plane between two kinds of sandstone's form soft-weak layer. Field investigations and reports by operators demonstrated that some instability problems might occur in the southern slope which is situated in zone I and zone II. Southern slope was divided into six sections (I-0, I-1, I-2, II-0, II-1 and II-2) to make the analysis. Slope stability analyses using limit equilibrium and numerical showed that the safety factors of some section are very low (section I-0, I-1, I-2) as a result of this, failure is likely to happen. Therefore reinforcement is very important to increase the safety factor of the three sections, two methods were used; Grouting to increase the slope cohesion (c) and Pre-stressed Anchor then the factor of safety increased more than 1.15 .
\end{abstract}

Keywords: Slope Stability, Limit Equilibrium Method, Numerical Method, Slope Reinforcement

\section{INTRODUCTION}

As the mining methods turning from open pit mining to sag by mining, vertical height of open-pit mine slope continues to increase the slope deformation and failure mode has close relationship with regional geological structure characteristics and the rock mass.

Structures feature, the stability is influenced largely by rock mass, joints and fissures and blasting vibration (Qiao and Li, 2004). Chengmenshan Copper Sulphur Mine "Fig. 1" is located in Chengmen County which lies about $18 \mathrm{~km}$ far from the west-south of Jiu Jiang, Jiang $\mathrm{Xi}$ province, China, $6 \mathrm{~km}$ far from Yangtze River. It is a large-scale CopperSulphur open pit mine of Jiangxi Copper Industry Company. The reserves are about 1.65 Mt Copper, 69t Gold and 35.66 Mt of Sulfur, the production is $0.2 \mathrm{Mt}$ of Ore (mining volume) and $1.25 \mathrm{Mt}$ of waste (stripping volume) per year. The pit was designed (with a width of $1250 \mathrm{~m}$, length of $1400 \mathrm{~m}$ and depth till $430 \mathrm{~m}$ ). The height of the bench was designed at $24 \mathrm{~m}$ and the overall slopes angle is about $50^{\circ}$.

The east, west and north side of Chengmenshan Copper-Sulfur mine is surrounded by lake's water; the South side is only land and transportation road of the mines production, which has been in service for many years. The engineering geology and hydrogeology in the southern mine area is very complicated and there are $F_{1}$ faults which run from east to west and anti-dip against the open pit near the southern slope. The slope consists mainly of two kinds of sandstone's of Shamao formation $\left(\mathrm{S}_{3} \mathrm{~s}\right)$ and Wutong formation $\left(\mathrm{D}_{3} \mathrm{~s}\right)$. The slope of the deep limestone, altered limestone and mineralized zones filling material formed a soft-weak layer in the contact plane. Due to weathering and erosion of the weak layer, strength is very low and also the soft weak layer is parallel to the slope, this therefore seriously threatens the stability of the slope.

Corresponding Author: Mohammed Mnzool, College of Resource and Environmental Science, Chongqing University, Chongqing 400030, China 


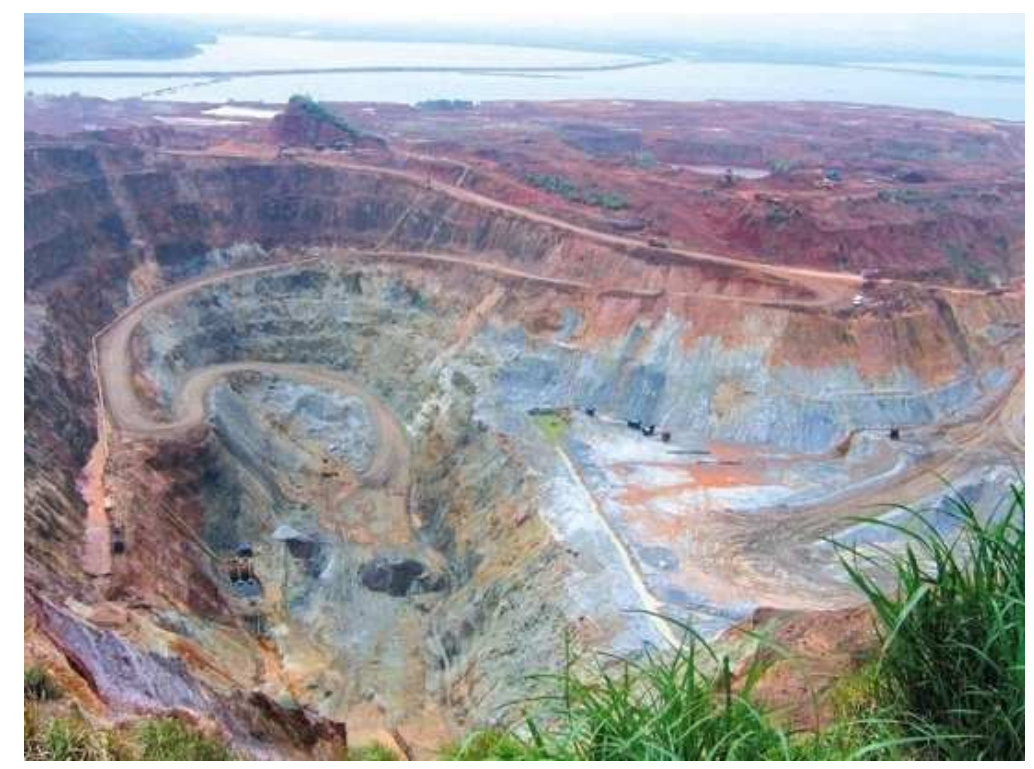

Fig. 1. View of Chengmenshan Copper Mine

\section{ENINEERING GEOLOGICAL AND CHARACTRISTICS OF THE SOUTHREN SLOPE}

Chengmenshan mining area is about $550 \mathrm{~km}^{2}$, the geotectonic position of the mining area is part of Yangtze met platform, Yanze-Qiantang downward, Jiu jiang platform caved area "Fig. 2".

\subsection{The Characteristics of the Exposed Rock in the Region}

The main Rocks in the mine area was divided into six types as follow; granodiorite porphyry $(\gamma \delta \pi)$, Charty-limestone $\left(\mathrm{Ch}_{1} \mathrm{~s}\right)$, Purplish-red Sandstone $\left(\mathrm{S}_{3} \mathrm{~s}\right)$, Sandstone of Wutong formation $\left(\mathrm{D}_{3} \mathrm{w}\right)$, Carbonate limestone and Dolomitic Limestone, the engineering data of the six type of rocks are collected from different parts and depths of the early developed pit and subjected to shear tests, results are tabulated in "Table 1". The Southern slope consists of two kinds of rocks of Silurian period. Top series Shamao formation $\left(\mathrm{S}_{3} \mathrm{~s}\right)$ and Devonian period, top series Wutong formation, there is a limestone formation in the deep formation. Because of the weathering the contact plane between two kinds of Sandstone's of Shamao formation $\left(\mathrm{S}_{3} \mathrm{~s}\right)$ and Wutong formation has formed soft-weak layers a very low strength, the soft-weak layer is basically parallel to the dip of slope and seriously threat the stability of slope.

\subsection{Structural Geology}

Based on the distribution of structural properties, the mine was divided into six structural zones as illustrated in "Fig. 3". The Southern slope of the Chengmenshan is located at the north side of Chenmenshan Mountain this belongs to zone I and II, in the slope engineering geological structural zones. Wutong set of Pliocene series of Devoniau System $\left(D_{3} w\right)$ is the Southern side of fault F1 this formation form the Southern slope of South pit which is quartzose Sandstone.

There are many sets of fissure structures in mining area, the main joint system nearby $F_{1}$ reverse thrust zone of Wutong sets rock near the fault zone, the joint fissures can be divided into five sets "Table 2", these joints varies to some extent in different tectonic positions. The joints system of the intrusive body's in the top part in the rock alteration zone is always comparatively dispersed, the direction deflects at different positions.

\subsection{Hydrogeology}

The mining area is surrounded by lake water, only the south side is land, the Southern slope is the only out trance of the mine, which has serviced the mine for long time. The mining area is situated in Ruichang river basin of Changjion; middle-lower Raches Saihu Lake's area, The highest annual precipitations $2165.7 \mathrm{~mm}$ and the least $868.3 \mathrm{~mm}$, the mean is about $1400 \mathrm{~mm}$, from March to August per annum its rain season, the precipitation during this time accounts for 70 to $80 \%$ of the annual precipitation for April, May and June. 
Mohammed Mnzool et al. / American Journal of Geosciences 3 (1): 13-22, 2013

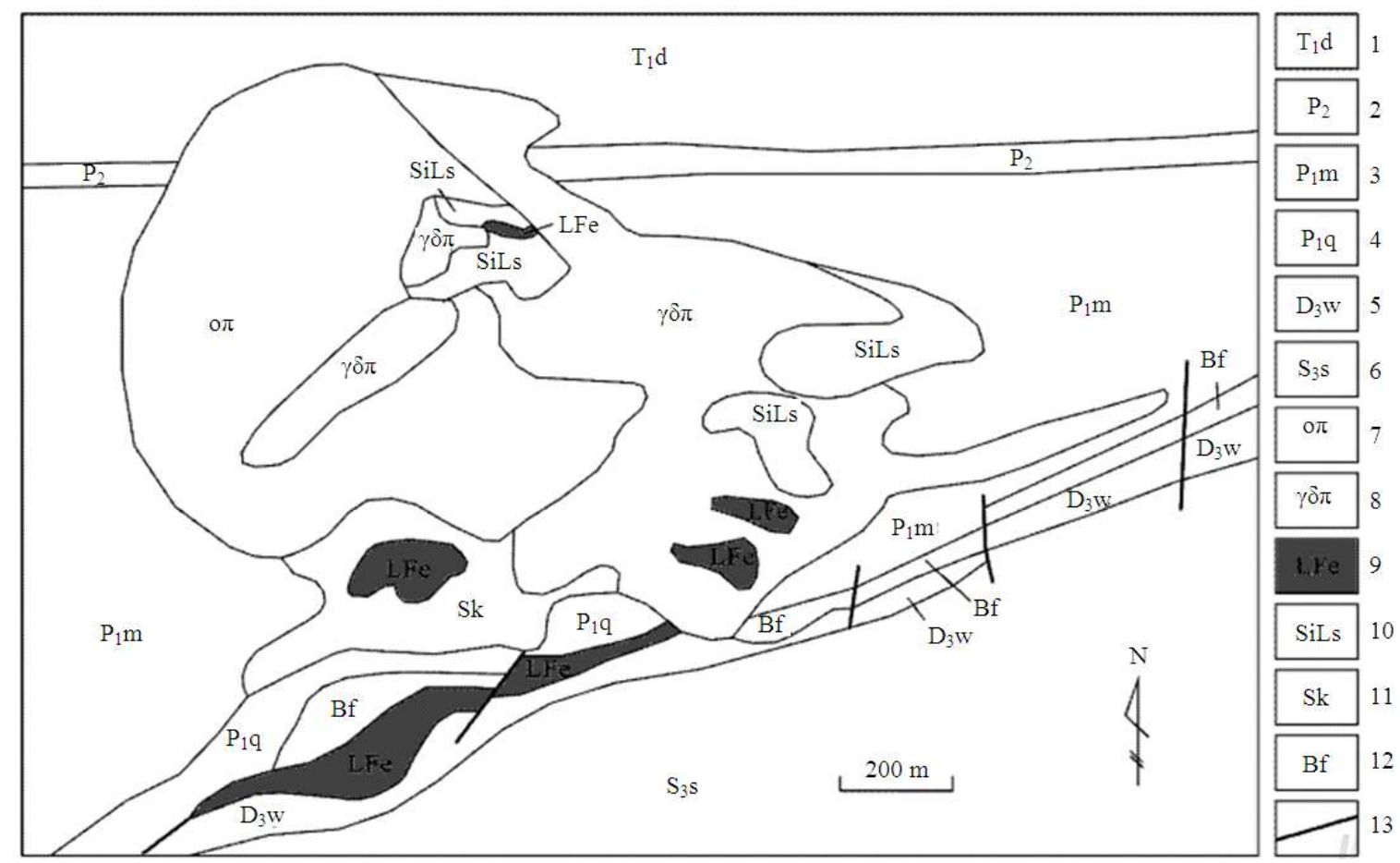

Fig. 2. Regioal geology map of Chengmenshan Copper Mine; 1-T1d- Limestone of lower Triassic Daye Formation; 2- P2- Upper Permian shale; 3-P1m Limestone of Lower Permian Maokou Formation; 4-P1q Limestone of Lower Permian Qixia Formation; 5- D3w- Sandstone of Upper Devonian Wutong Formation; 6- S3s Sandston of Upper Silurian Shamao Formation; 7- O $\pi$ Quartz porphyry; 8- $\gamma \delta \pi$ Granodiorite porphyry; 9- LFe Gossan; 10- SiLs Silicified Limestone; 11- Sk Skam; 12- Bf Fracture zone; 13- Fault

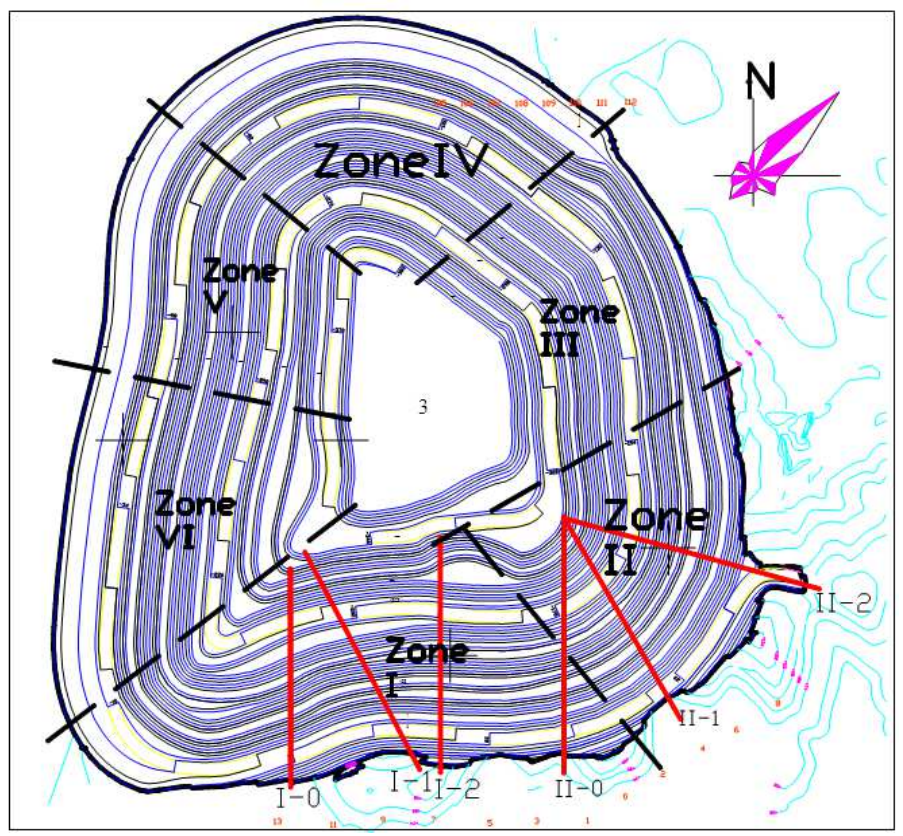

Fig. 3. Structural Zones and sections of southern slope of Chengmenshan Mine 
Table 1. Determination of cohesion (c) and friction angle $(\varphi)$

\begin{tabular}{|c|c|c|c|c|}
\hline \multirow[b]{2}{*}{ Lithotlogy } & \multicolumn{2}{|c|}{ Strength Protolith } & \multicolumn{2}{|c|}{ Parameter Weak surface } \\
\hline & $\mathrm{C}(\mathrm{MP})$ & $\varphi\left({ }^{\circ}\right)$ & $\mathrm{C}(\mathrm{MP})$ & $\varphi\left({ }^{\circ}\right)$ \\
\hline $\begin{array}{l}\text { Granodiorite } \\
\text { porphyry }(\gamma \delta \pi)\end{array}$ & 0.63 & 32 & 0.03 & 26 \\
\hline Charty-Limestone (Ch1s) & 0.48 & 40 & 0.018 & 29 \\
\hline $\begin{array}{l}\text { Purplish-red } \\
\text { Sandstone (S3s) }\end{array}$ & 0.46 & 35 & 0.04 & 29 \\
\hline $\begin{array}{l}\text { Sandstone of } \\
\text { Wutong (D3w) }\end{array}$ & 0.08 & 44 & 0.06 & 29 \\
\hline $\begin{array}{l}\text { Carbonate limestone } \\
\text { Carbonate limestone }\end{array}$ & - & - & $\begin{array}{l}0.02 \\
0.042\end{array}$ & $\begin{array}{l}27 \\
26\end{array}$ \\
\hline
\end{tabular}

Table 2. Characteristics of discontinuities

\begin{tabular}{|c|c|c|c|c|}
\hline No of set & $\operatorname{Dip}\left({ }^{\circ}\right)$ & Dip direction $\left(^{\circ}\right)$ & Mechanical property & Features \\
\hline JS1 & $50 \sim 85$ & $150 \sim 170$ & Compression & The joint surface is straight and filled with Pyrite \\
\hline JS2 & $50 \sim 70$ & $330 \sim 350$ & Compression & The joint surface is straight and filled with Pyrite \\
\hline JS3 & $60 / 70 \sim 80$ & $240 / 70 \sim 80$ & Tensional & $\begin{array}{l}\text { The joint surface is pectional and the fissure is } \\
\text { wide but nott long and filled with pyrite. }\end{array}$ \\
\hline JS4 & $\begin{array}{l}50 \sim 80 / \\
50 \sim 80\end{array}$ & $\begin{array}{l}290 \sim 300 / \\
110 \sim 120\end{array}$ & Contorted & The joint is straight and filled a little \\
\hline JS5 & $\begin{array}{l}50 \sim 80 / \\
50 \sim 80\end{array}$ & $\begin{array}{l}60 \sim 88 / \\
240 \sim 268\end{array}$ & Contorted & The joint is straight and filled a little \\
\hline
\end{tabular}

In additional there are other open water in the mining and nearby the area like: Yangtze River it is about $6.5 \mathrm{~km}$ from the mining area, Rutchang river which form by joining Idenggang River and Wushi River, Saihu Lake the water mainly comes from Ruichang River and Chengmen lake which lies on the west south of the mining area.

In the mining area, groundwater is recharged by the groundwater of Western County from the area of Guilingquao. The general flow direction is from west to east with a hydraulic gradient of about $1 / 10000$ and the water table drops in the dry season to less than $3 \mathrm{~m}$. The existing data indicates that there is no direct dynamic connection between lake water and groundwater in the unaffected condition and small drawdown pumping one.

The hydrogeology condition is very complicated. The main problem is that it is possible to cause karst collapse in the bottom of the lake by pumping and to pour lake water into underground as well as to dewater the open mine. In order to solve this problem, a mathematic model for dewatering karst water in the complicated hydrogeology condition was established. The quantity and percentage of each source of mine drainage were calculated by numerical computation. The possibilities of karst collapses caused by pumping and pouring lake water into mine happening through collapses were studied. At last it is demonstrated that groundwater can be harnessed. Generally we can say that the south side of the mine is only land, the effects of hydrogeology in Southern slope has been controlled.

\section{THE SOUTHREN SLOPE ANALYSIS OF CHENGMENSHAN}

The southern slope of Chengmenshan is the only out trance of the mine which has serviced the mine for many years, the engineering geology and hydrogeology in the southern slope is very complicated and there are $\mathrm{F}_{1}$ fault near the slope. The slope mainly consists of two kinds of sandstones of Wutong formation $\left(\mathrm{S}_{1} \mathrm{~s}\right)$ and Shamao formation $\left(\mathrm{D}_{3} \mathrm{w}\right)$, because of the weathering the contact plane between two kinds of Sandstone's of Shamao formation $\left(\mathrm{S}_{3} \mathrm{~s}\right)$ and Wutong formation has formed soft-weak layer parallel to the dip, however, the layer seriously threaten the stability of slope "Fig. 4".

During the production of the mine, many studies have been done on slope stability of the southern part of Chengmenshan Copper mine by Nanchang design Institute. According to the geotechnical study the mine was classified into 6 zones of engineering geology (I, II, III, IV, $\mathrm{V}$ and VI) as shown in "Fig. 3". Field investigations and reports by operators demonstrated that some instability problems might occur in the southern slope which is situated in zone I and zone II. The southern slope of Chengmenshan was divided in to six sections (I- $0, \mathrm{I}-1, \mathrm{I}-2$, II-0, II-1 and II-2) to make the analysis. 


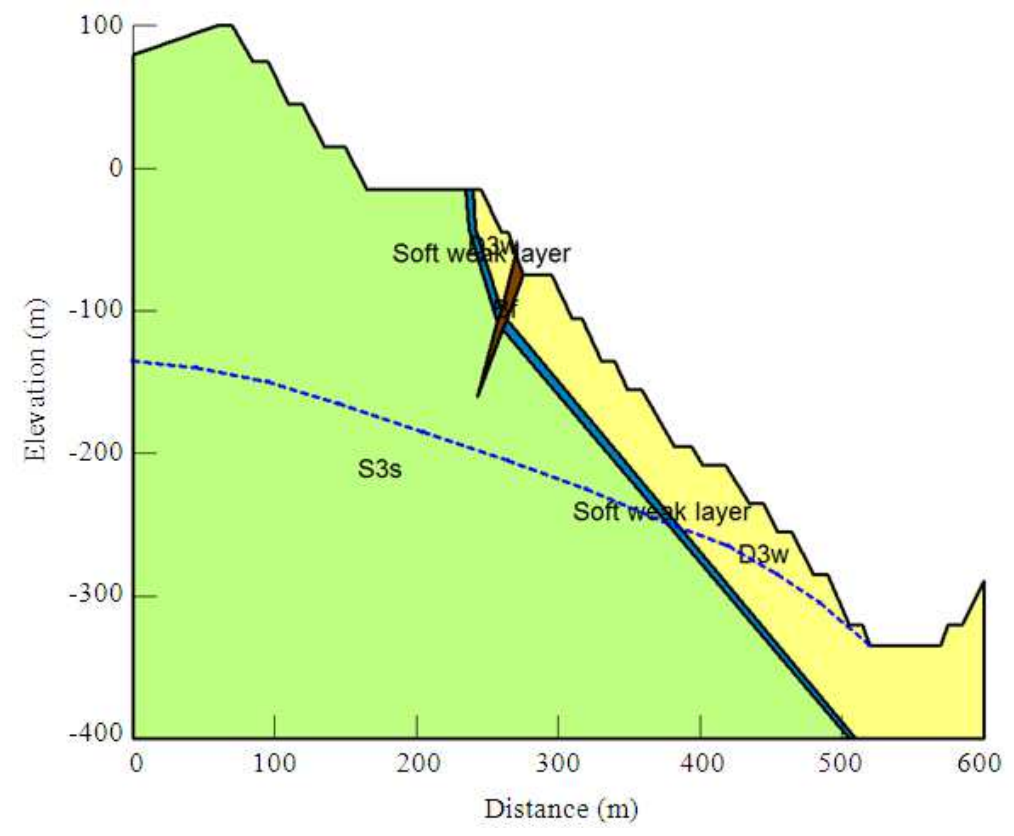

Fig. 4. Soft weak layer Section I-2

Table 3. Result of strength tests of southern slope

\begin{tabular}{lllll}
\hline Slope Materials & Limestone & Sandstone & Sandstone & Soft-weak \\
\hline Properties & $(\mathrm{p} 1 \mathrm{q})$ & Shamao $(\mathrm{S} 3 \mathrm{~s})$ & Wutong (D3w) & layer \\
Cohesion c $(\mathrm{M} \mathrm{Pa})$ & 0.48 & 0.46 & 0.08 & 0.05 \\
Friction angle $\phi(\phi)$ & 40 & 35 & 44 & 29 \\
Unit weight $\gamma\left(\mathrm{KN} / \mathrm{m}^{3}\right)$ & 25 & 25 & 25 & 25 \\
\hline
\end{tabular}

\subsection{Required Engineering Geology Data for Slope Analysis}

The parameters, required for stability analysis are comprised of rock mass strength, water ground level and earthquake loading (Ataei and Bodaghabadi, 2008). The shear strength is one of the most important parameters of slope design. The results of the strength tests (cohesion c, friction angle $\phi$, unit weight $\gamma$ ) of rocks type in Chengmenshan Copper mine southern slope are tabulated in "Table 3", these data are the basic of calculate the stability analysis of the slope.

Ground water is one of the most important issues in geomechanical analyses which play a significant role in stability (Ataei and Bodaghabadi, 2008). In spite of surrounding water of three parts of the mine, seriously threaten the stability of slope "Fig. 4". The southern slope was only land groundwater existing in the sections (I-1, I-2, II-1). The data for the effects of the explosion and earthquake in the area were obtained from JiuJiang province for the years 1971-1991 which showed a seismic shock impact factor of $\left(\mathrm{k}_{\mathrm{c})}=0.021\right.$. Moreover in the first three sections I-0,I-1,I-2 of the southern slope, there was a soft weak layer between the purplish red sandstone of the Wutong $\left(\mathrm{S}_{1} \mathrm{~s}\right)$ and Shamao formation $\left(\mathrm{D}_{3} \mathrm{w}\right)$ is parallel to the slope surface which seriously threaten the slope stability"Fig. 4".

\subsection{The Slope Stability Calculation}

The permitted factor of safety is an important index toevaluate the stability of the slope, to determine this factor is a complex problem. Generally it depends on several factors for examples engineering geology, hydrogeology and period of the mine production and so on. Considering the experience of domestic and abroad, the permit factor of slope safety is determined as $\mathrm{K}=1.22$, if we consider the effect of water and dynamic explosion, soft weak layer, the permit factor of slope is $\mathrm{K}=1.15$. 
To calculate the Safety factor of the sex section two methods were used; first Stability analysis using limit equilibrium theory, were carried out using Geo Studio (2007 Ver.7.10) geo-slope Bishops method and Slide Ver.5.014. The second method was a numerical analysis, performed with Phase 2 Ver.8.010. The calculation of the safety factor was divided in two parts, the first part had only the self weight of the slope materials while the second part considered the effect of water, seismic and weak layers. The results are illustrated in the "Table 4".

Slope stability analyses showed that the safety factors of some section were very low "Table 4" section I-0, I-1 and I-2). As a result of the weak layer, failure is likely to happen, "Fig. 5-6" illustrate the total displacement, display elements and Shear Strength Reduction Convergence of Section I-2. To increase the value of safety factor there was need to make some reinforcements to the Southern slope. Different methods were used Anchors reinforcement were established as shown in the Sections "Fig. 7-10".

\section{SOUTHERN SLOPE REINFORCEMENT PROGRAMS}

\subsection{Pre-Grouting Increase Solid Program}

Pumping the cement slurry into the sliding surface with high pressure along the slope using a variety of channels to penetrate the landslide body, squeezing out water and cracks in the sliding surface in the water and then increase the sliding soil shear strength. Grout reinforcement with hydration of cement and water, so that the slope cohesion (c) value increased and then improving the strength of the landslide. The program of construction technology was found to be safe, convenient and cost effective, costing 7.8 million Yuan only. However, the main problem is that the domestic and international engineering examples on the grouting effect are difficult to make using accurate quantitative evaluation.

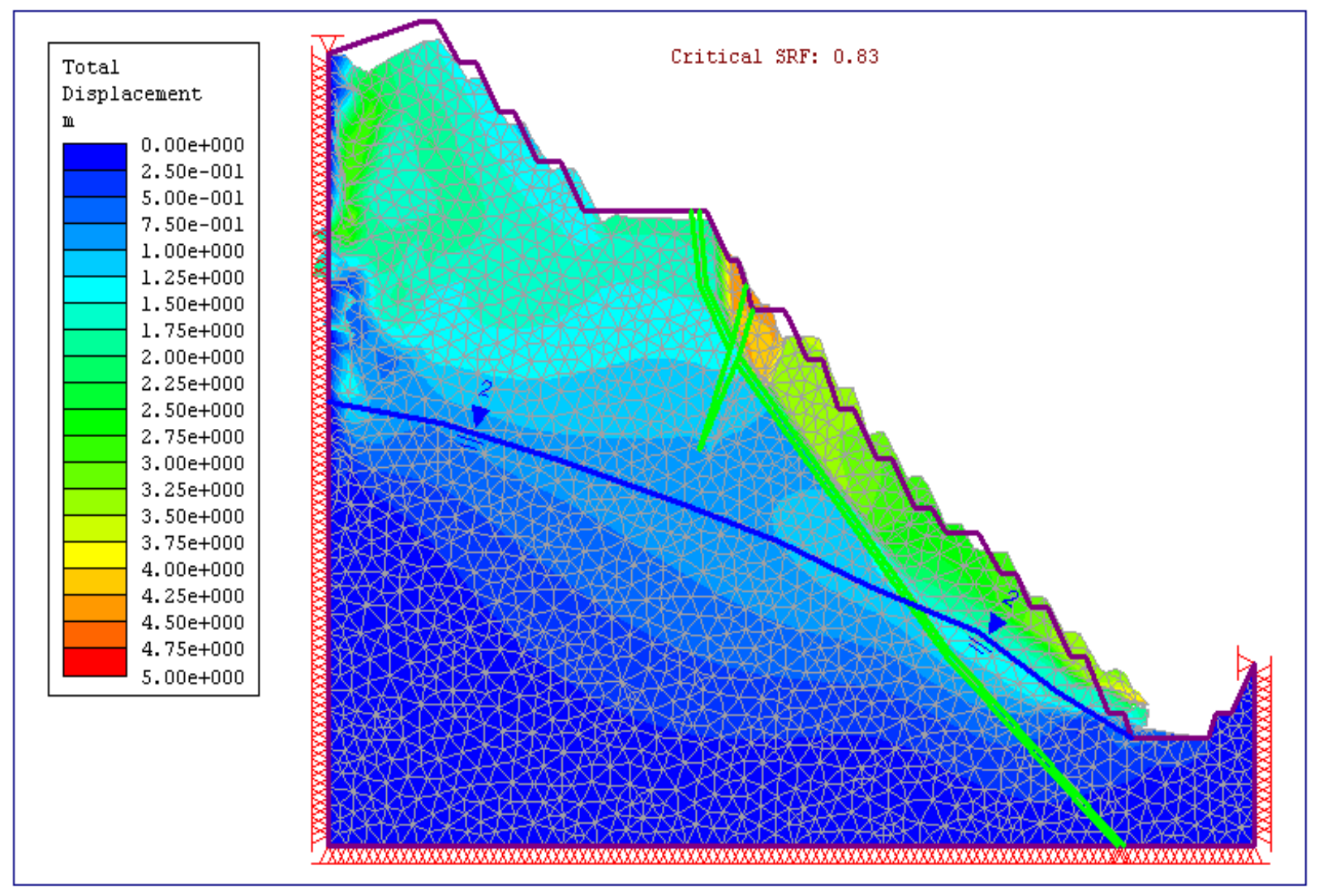

Fig. 5. Section 1-2 Total displacement and display elements 
Mohammed Mnzool et al. / American Journal of Geosciences 3 (1): 13-22, 2013

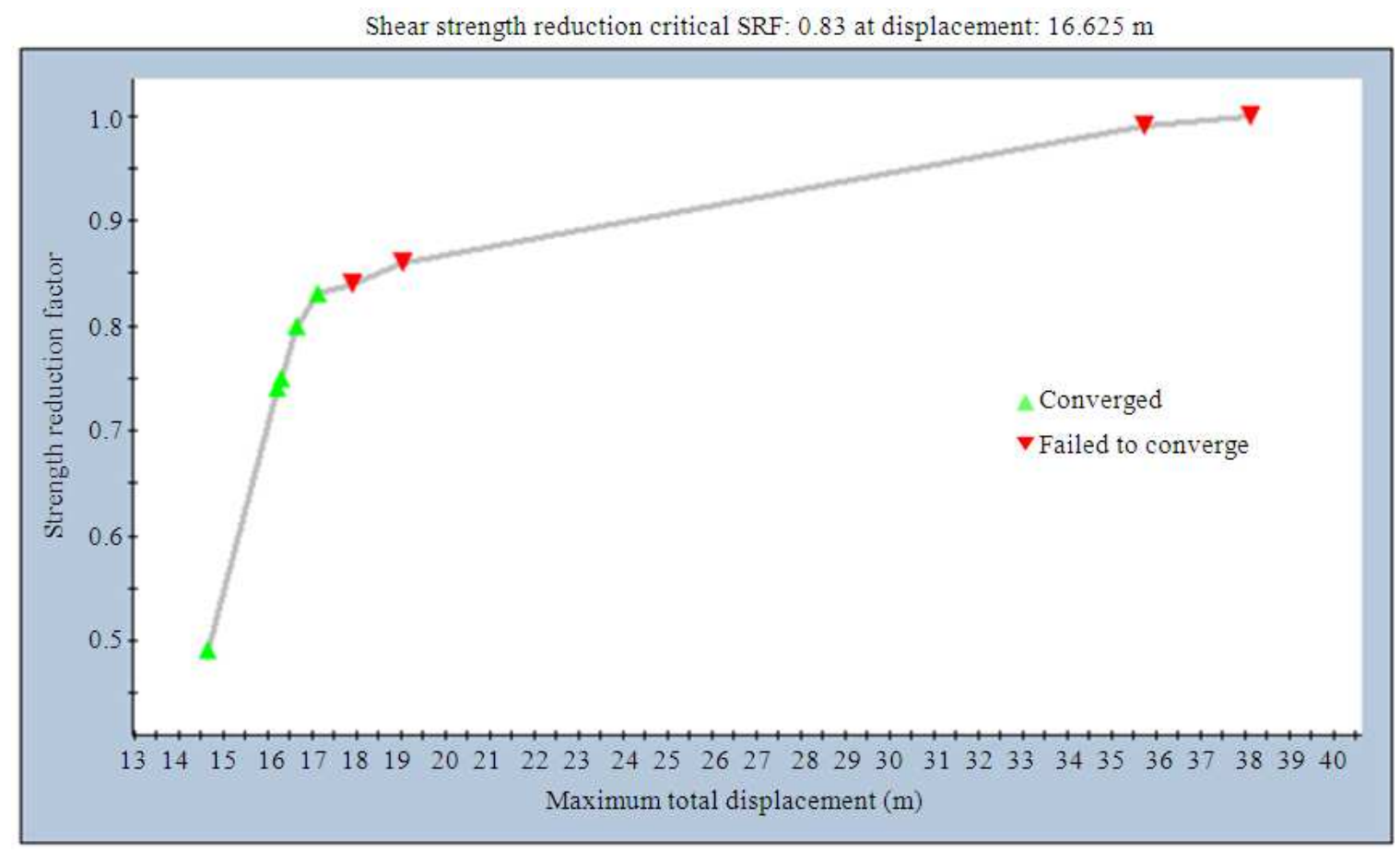

Fig. 6. Shear strength reduction convergence graph of analysis section I-2

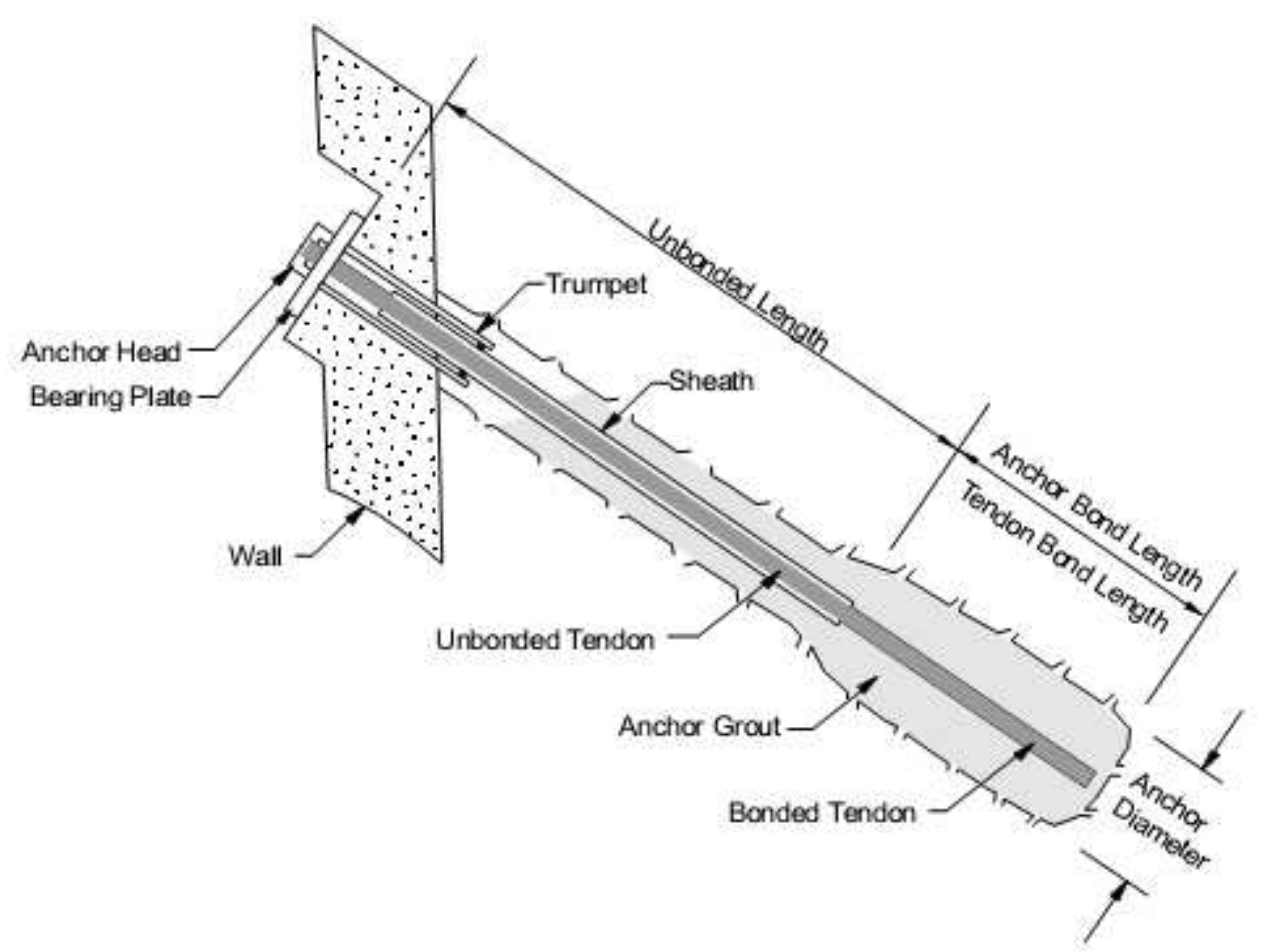

Fig. 7. Components of ground anchor of Sabatini, PJ (Windsor and Thompson, 1992) 
Mohammed Mnzool et al. / American Journal of Geosciences 3 (1): 13-22, 2013

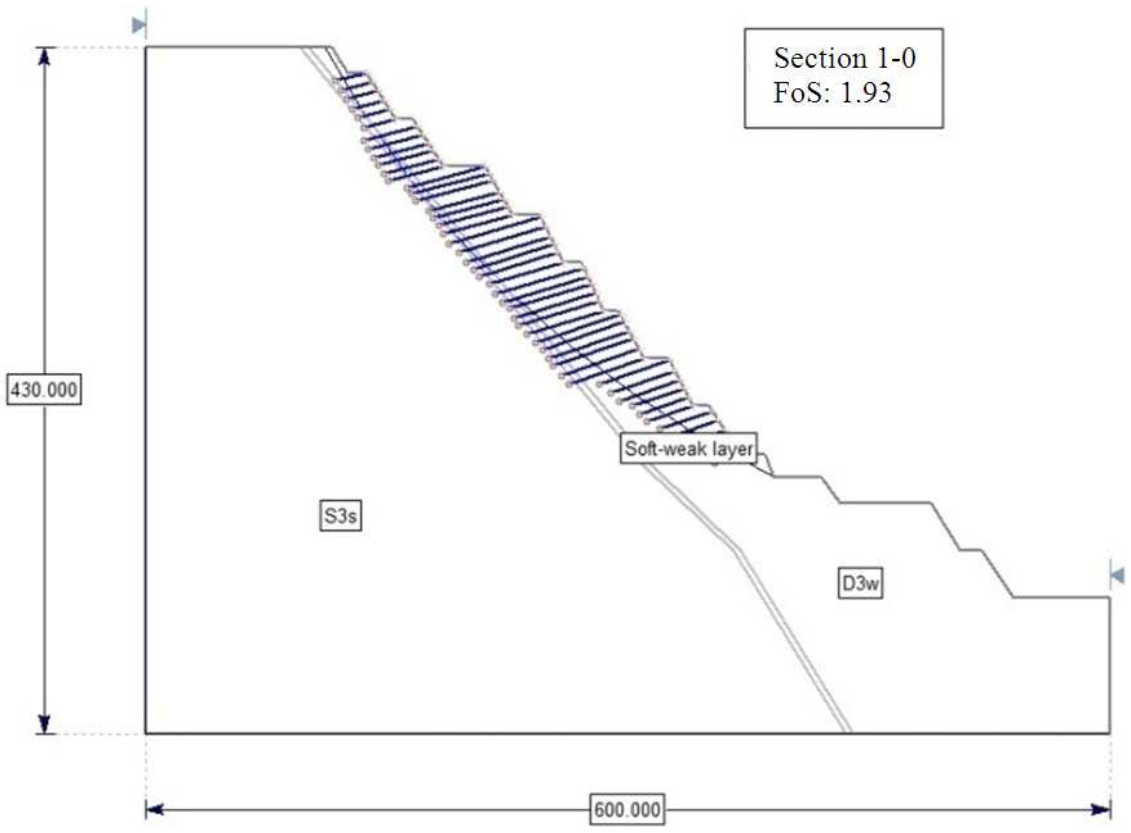

Fig. 8. Anchor reinforcement section I-0

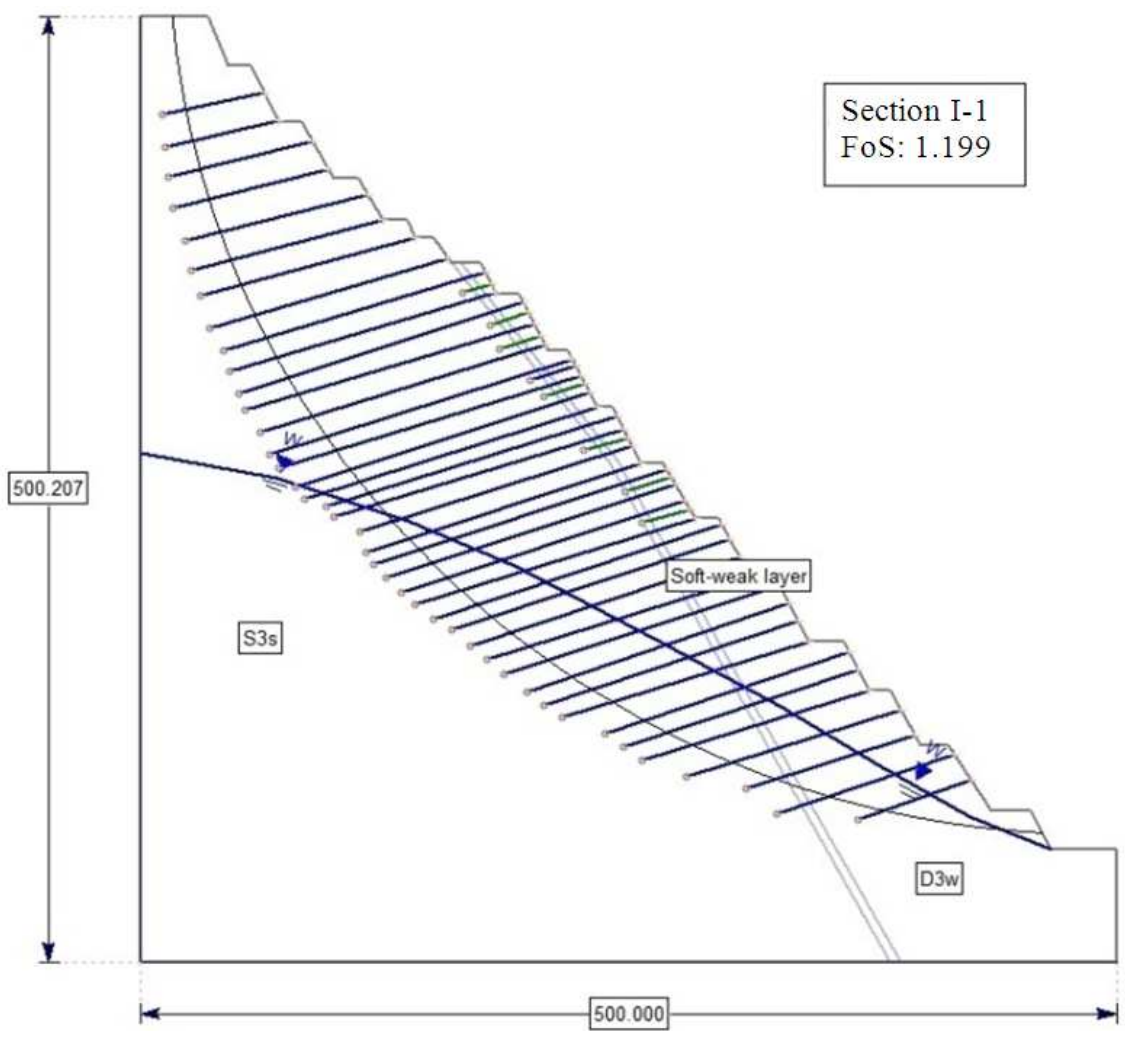

Fig. 9. Anchor reinforcement section I-1 


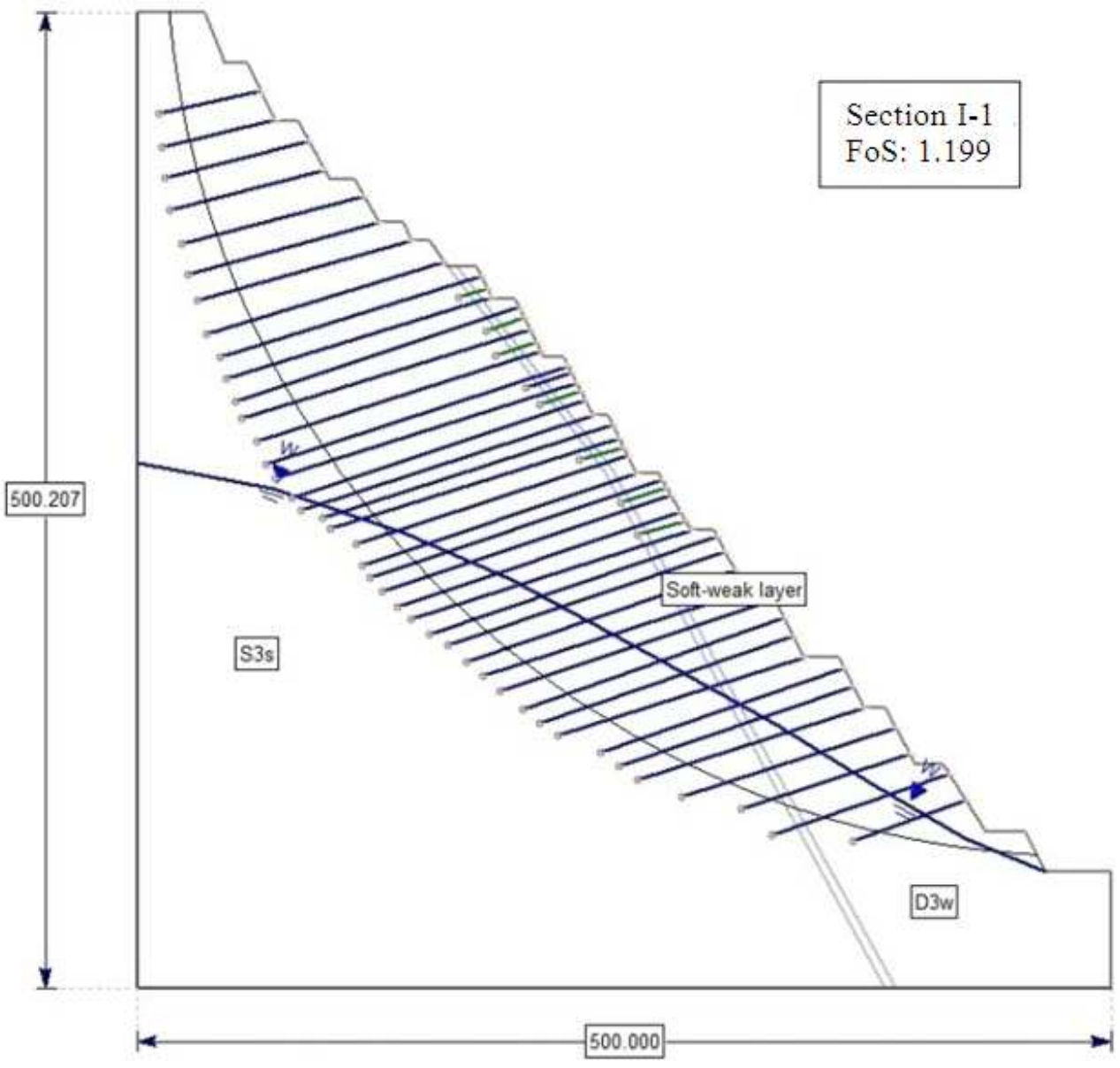

Fig. 10. Anchor reinforcement section I-2

Table 4. Minimum safety factor of the six sections

\begin{tabular}{|c|c|c|c|c|c|c|}
\hline \multirow[b]{2}{*}{ Sections } & \multicolumn{2}{|c|}{ F of Safety GeoStudio } & \multicolumn{2}{|c|}{ Factor of Safety Slide } & \multicolumn{2}{|c|}{ Factor of Safety Phase2 } \\
\hline & $\begin{array}{l}\text { Bishop } \\
\text { Self-weight }\end{array}$ & $\begin{array}{l}\text { Sei+w } \\
+ \text { weak layer }\end{array}$ & $\begin{array}{l}\text { Bishop } \\
\text { Self-weight }\end{array}$ & $\begin{array}{l}\text { Sei+w } \\
+ \text { weak layer }\end{array}$ & $\begin{array}{l}\text { SSR } \\
\text { Self-weight }\end{array}$ & $\begin{array}{l}\text { Sei+w } \\
+ \text { weak layer }\end{array}$ \\
\hline $\mathrm{I}-0$ & 1.27 & 1.23 & 1.25 & 1.02 & 1.19 & 0.92 \\
\hline $\mathrm{I}-1$ & 1.20 & 1.10 & 1.15 & 0.90 & 1.15 & 0.91 \\
\hline $\mathrm{I}-2$ & 1.18 & 1.00 & 1.20 & 1.05 & 1.03 & 0.79 \\
\hline II-0 & 1.31 & 1.27 & 1.41 & 1.36 & 1.29 & 1.25 \\
\hline II-1 & 1.24 & 1.18 & 1.24 & 1.17 & 1.13 & 1.09 \\
\hline II-2 & 1.33 & 1.32 & 1.31 & 1.27 & 1.18 & 1.13 \\
\hline
\end{tabular}

\subsection{Reinforcement with Pre Stressed Anchor}

The development of mine engineering and road engineering had prompted some scholars to perform research on rock slope reinforcement through field monitoring, laboratory tests and numerical simulation (Chen and Jia, 2010). Windsor and Thompson (1992) developed a design and analysis package for rock reinforcement. Ground anchors can be used to provide a sufficiently large force to stabilize the mass of ground above the landslide or slip surface (Sabatini et al., 1999). Pre stressed Anchor reinforcement has been done to the three sections to increase the factor of safety by more than 1.15. Back analysis was done to get the 
amount of the reinforcement force in every section. Slide and Geo-studio software was used to make the calculations. The components of the ground anchor shown are in "Fig. 7". parameters of the pre stressed anchor are; constant applied load $600 \mathrm{KN}$, the bond length $6 \sim 10 \mathrm{~m}$, bond friction area $300 \mathrm{kPa}$, anchor spacing 2m, Bar Capacity 2000kNand anchors length between 10 to $60 \mathrm{~m}$ as shown in "Fig. 5". Sections I0, I-1, I-2 are after Anchor support, while the figures from 8 to 10 illustrates the Anchor reinforcement of the three sections I-0,I-1, I-2.

\section{CONCLUSION}

The engineering geology and hydrogeology in the Southern slope of Chengmenshan is very complicated and there are $F_{1}$ faults near the slope. The slope consists mainly of two kinds of sandstones of Wutong formation $\left(\mathrm{S}_{1} \mathrm{~s}\right)$ and Shamao formation $\left(\mathrm{D}_{3} \mathrm{w}\right)$. Because of the formation has formed soft-weak layers very low strength which threats the stability of slope. The soft-weak layer is basically parallel to the dip of slope and seriously. According to the geotechnical study the mine was classified into 6 zones of engineering geology (I, II, III, IV, V and VI). The engineering data of the six types of rocks were collected from different parts and depths of the early developed pit and subjected to shear tests. Field investigations and reports by operators demonstrated that some instability problems might occur in the southern slope which is situated in zone I and zone II. The southern slope was divided in to six sections (I-0, I-1, I-2, II-0, II-1 and II-2) to make the analysis. After the six sections were drown to make the analysis of the slope. Stability analysis performed with Geoslope and Slide as limit equilibrium based software and with Phase 2 as numerically based software. Slope stability analyses showed that the safety factors of some section are very low (section I-0, I-1, I-2) because of the weak layer failure is likely to take place. The study showed that reinforcement is very important to increase the safety factor of the three sections. Two methods were used to make the reinforcement: Grout reinforcement with hydration of cement and water, so that the slope cohesion (c) value increased and then improve the strength of the landslide and Pre stressed Anchor reinforcement has been done to the three sections to increase the factor of safety by more than
1.15. Back analysis was done to get the amount of the reinforcement force in every section, Slide and Geostudio software was used to make the calculation.

\section{REFERENCES}

Ataei, M. and S. Bodaghabadi, 2008. Comprehensive analysis of slope stability and determination of stable slopes in the Chador-Malu iron ore mine using numerical and limit equilibrium methods. J. China Univ. Min. Technol., 18: 488-493. DOI: 10.1016/S1006-1266(08)60281-3

Chen, G. and J. Jia, 2010. Case study of slope stabilization using compression anchor and reinforced concrete beam. Proceedings of the Boundaries of Rock Mechanics: Recent Advances and Challenges for the 21st Century, (ACC '10), Taylor and Francis, pp: 455-458. DOI: 10.1201/9780203883204.pt4

Qiao, L. and Y. Li, 2004. Engineering geological model of high-steep slope damage in opencut mines. Beijing Keji Daxue Xuebao/J. Univ. Sci. Technol. Beij., 26: 461-464.

Sabatini, P., D. Pass and R. Bachus, 1999. Geotechnical engineering circular no. 4: Ground anchors and anchored systems.

Windsor, C.R. and A.G. Thompson, 1992. Reinforcement design for jointed rock masses. Proceedings of the 33rd US Symposium on Rock Mechanics, Santa Fe, Rock Mechanics, (FRM '92), Rotterdam, pp: 1-10. 